\title{
Neuroprotective effects of albumin, pioglitazone and insulin against ischemic brain damage in mice
}

Lotfy A. M.*, Barakat W., Abd El ghany R. H.

Pharmacology Department, Faculty of Pharmacy, Zagazig University, Egypt. *Correspondence Author E-mail: Ahmedlotfy1612010@yahoo.com

\section{ABSTRACT}

Stroke is a leading cause of death and permanent disability in adults worldwide. Intravenous recombinant tissue plasminogen activator (rt- PA) is the only FDA-approved treatment for administration within 3 hours of onset of acute ischemic stroke. The current study has investigated neuroprotective effects of human serum albumin (20\% solution) (HSA) in a vehicle (sodium chloride $0.09 \%)(0.04 \mathrm{ml} / 20 \mathrm{~g})$ was administrated intravenous at a constant rate over $3 \mathrm{~min} 2 \mathrm{~h}$ after the onset of ischemia. Pioglitazone $(40 \mathrm{mg} / \mathrm{kg} / \mathrm{day}$, as a suspension in $0.5 \%$ carboxymethylcellulose) was orally administrated for three days before ischemia and for two days after ischemia. Insulin was administrated $0.3 \mathrm{IU} / \mathrm{kg}$ (via tail vein) at the beginning of MCAO and after $6 \mathrm{~h}$ of MCAO. Human serum albumin (HAS), pioglitazone and insulin demonstrated neuroprotective effects against brain damage induced by permanent MCAO in mice as evidenced by the reduction in initiation of walking time and prevention of leukocyte infiltration and brain edema.

Key words: Albumin-pioglitazone-insulin-stroke-ischemia-tissue plasminogen activator

\section{INTRODUCTION}

Stroke is the second leading cause of death in industrialized countries and the most frequent cause of permanent disability in adults worldwide (Lipton, 1999; Woodruff et al., 2011). It is a multifactorial disease in which neuronal cell death proceeds through a mixture of mechanisms including oxidative stress, excitotoxicity, apoptosis, and inflammation (Van Leyen et al., 2006). Human serum albumin (20\% solution) (HSA) in a vehicle (sodium chloride $0.09 \%$ ) was administration intravenous ( $1 \%$ body weight) at a constant rate over $3 \mathrm{~min}$ immediately $2 \mathrm{~h}$ after onset of ischemia (Huh et al., 1998). This dose for rat, so convert it to dose of mice is $(0.04 \mathrm{ml} / 20 \mathrm{~g})$. Human serum albumin (HAS) has been studied as a hemodiluent in several previous reports (Aronowski et al., 1996; Cole et al., 1996). HAS inhibits platelet aggregation (Jorgensen and Stoffersen, 1980) and influences erythrocyte aggregation, increasing lowshear viscosity (Reinhart and Nagy, 1995). Several reports strongly support a physiological role for human serum albumin as a scavenger of oxygen free radicals (Wasil et al., 1987; Halliwell and Gutteridge, 1990). Pioglitazone (40 mg/ kg/ day), as a suspension in $0.5 \%$ carboxymethylcellulose was administrated orally for three days before ischemia and two days after ischemia. Carboxymethylcellulose solution was administered to mice as a vehicle according to the same volume and time schedule of pioglitazone (Lee et al., 2009). Pioglitazone is a synthetic PPAR- $\gamma$ agonist, acts as an insulin sensitizer and is used in the treatment of type 2 diabetes. Pioglitazone was previously reported to mediate intracerebral activation of PPAR- $\gamma$ and inhibition of inflammatory responses at early time points after stroke (Zhao et al., 2005). In addition, pioglitazone was shown to down regulate tumor necrosis factor- $\alpha$ (TNF- $\alpha)$, interleukin$1 \beta$ (IL-1 $\beta$ ) and IL-6 (Wang et al., 1996; Jiang et al., 1998; Streitet al., 1998; Lee et al., 2000; Niino et al., 2001; Pineau and Lacroix, 2007). PPAR- $\gamma$ agonists attenuate 
the expression of ICAM-1, matrix metalloproteinase (MMP)-9 and many other inflammatory cytokines following brain ischemia (Pereira et al., 2005; Luo et al., 2006; Culman et al., 2007). Insulin dose 0.3 IU/ $\mathrm{kg}$ via tail vein at the beginning of MCAO and $6 \mathrm{~h}$ after MCAO. Sodium chloride $\quad 0.09 \%$ was administrated intravenous via tail vein to mice as a vehicle according to the same volume and time schedule of insulin. This dose was selected based on a pervous study in rats (Collino et al., 2009). This dose for rat, so convert it to dose of mice $\left(2 \mathrm{IU}^{*} 0.15=0.3 \mathrm{IU}\right)$. Animal and human studies demonstrate that insulin reduces brain damage evoked by ischemia/ reperfusion (I/R) injury (Hui et al., 2005; Rizk, et al., 2006). Insulin is a wellcharacterized inhibitor of the activation of the glycogen synthase kinase-3 beta (GSK33) (Cohen and Goedert, 2004). GSK-3 has emerged as a key regulatory switch in the modulation of neurodegeneration and inflammation (Martinez et al., 2002; Dugo et al., 2007).

In the current study, brain ischemia was induced by permanent middle cerebral artery occlusion (MCAO) to estimate the possible protective role of human serum albumin, pioglitazone and insulin against brain injury induced in mice.

\section{Material and methods}

\section{Animals}

Adult male balb-c mice aged 8-12 weeks weighing 20-25 gm were purchased from the Theodore Bilharz Research Institute, Cairo, Egypt. The mice were kept under standard environmental and nutritional conditions throughout the investigation. All experiments were carried out in accordance with the EU Directive 2010/63/EU on the protection of animals used for scientific purposes and were approved by the Ethical Committee for Animal Handling at Zagazig University (ECAHZU)

\section{Experimental design}

108 adult male balb-c mice aged 8-12 weeks weighing 20-25 gm were randomly distributed into 3 major groups as follows:

Albumin group (A) which was subdivided into: Sham group (A Sham) treated with vehicle (intravenous $0.9 \%$ saline), MCAO group (A MCAO) treated with vehicle (intravenous $0.9 \%$ saline) at a constant rate over $3 \mathrm{~min}$ immediately $2 \mathrm{~h}$ after onset of ischemia and Albumin group (Albumin) treated with human serum albumin (20\% solution) (HSA) in a vehicle (saline $0.9 \%$ ) was administration intravenous $(0.04 \mathrm{ml} / 20 \mathrm{~g})$ at a constant rate over $3 \mathrm{~min}$ immediately $2 \mathrm{~h}$ after onset of ischemia.

Pioglitazone group (P) which was subdivided into: Sham group (P Sham) treated with the vehicle (oral $0.5 \%$ carboxymethylcellulose), MCAO group (P MCAO) treated with the vehicle (oral $0.5 \%$ carboxymethylcellulose) and pioglitazone group (pioglitazone) treated with pioglitazone $(40 \mathrm{mg} / \mathrm{kg} / \mathrm{day})$ as a suspension in $0.5 \%$ carboxymethylcellulose was administration orally in divided dose daily for three days before ischemia and two days after ischemia.

Insulin group (I) which was subdivided into: Sham group (I Sham) treated with the vehicle (intravenous $0.9 \%$ saline), MCAO group (I MCAO) treated with the vehicle (intravenous $0.9 \%$ saline) and insulin group (insulin) treated with $0.3 \mathrm{IU} / \mathrm{kg}$ in $0.9 \%$ saline via tail vein at the beginning of MCAO and $6 \mathrm{~h}$ after MCAO

\section{Induction of ischemia}

Surgery was performed under anesthesia using tribromoethanol $(15 \mathrm{ml} / \mathrm{kg}$ of $2 \%$, intraperitoneal, Sigma Aldrich, Germany) (Muhammad et al., 2008; Barakatet al., 2009) and the animal body temperature was adjusted to $37 \pm 1^{\circ} \mathrm{C}$ during and after the operation until they regained consciousness (Barakat et al., 2009). MCAO was induced 
by using bipolar coagulator (ERPE, Electromedizin-GMPH, Germany) to occlude the MCA. Sham-operated mice were exposed to the same anesthesia and surgical procedure without electrocoagulation of MCA (Muhammad et al., 2008; Colak et al., 2011; Barakat et al., 2014). The mortality rate in the present study was less than $20 \%$, and less than $10 \%$ of the animals were devoid of ischemia (were excluded from the data analysis).

\section{Perfusion and sampling}

After 48 hours, the animals were anesthetized and the thoracic cavity was opened to expose the heart and visualize the ascending aorta. The animal was perfused using 18-gauge butterfly with $50 \mathrm{ml}$ Ringer's solution while a cut was made into the right atrium. The whole brain was cut from olfactory bulb to the cerebellum and preserved in formalin, washed by alcohol then xylene and mounted in wax. Then, it was cooled and cut by microtome at thickness $3 \mu \mathrm{m}$ on slides and stained by Hematoxlin and Eosin (H\&E) staining.

\section{Behavioural test to detect sensorimotor recovery}

The performance in the initiation-ofwalking test (latency to move) was used to assess the sensorimotor deficit based on the time needed for a mouse to move one body length $(7 \mathrm{~cm})$. This test was performed 3 times to calculate the mean-time one day before and two days after ischemia (Hattori et al., 2000).

Hematoxlin and Eosin (H\&E) staining to detect the brain edema, neuronal degeneration and leukocytes infiltration:

Brain sections were stained according to the method of Hematoxlin and Eosin (H\&E) staining (Mayer, 1896; Lillie, 1965; Avwioro, 2011). The sections were investigated under light micro scope and images were computed by using camera and the photos were analysed.

\section{Statistical analysis:}

Data are expressed as mean \pm standard deviation of mean (S.D.M). Statistical analysis was performed using one way analysis of variance (ANOVA) followed by Tukey's post Hoc test for comparisons between groups and paired $t$ test for comparing changes in behavior before and after MCAO using Graph pad Prism software version 5. For all analysis, the level of statistical significance was set at $\mathrm{P}<0.0001$.

\section{RESULTS}

\section{Effects on behavior: \\ Initiation-of-walking}

A significant sensorimotor dysfunction was observed in MCAO groups when compared to before ischemia using paired $t$ test as follow:

(A MCAO) group had a significant increase in the initiation of walking time when compared with the corresponding group before ischemia using paired $t$ test (2.93 sec vs. $0.67 \mathrm{sec}$ ). (P MCAO) group had a significant increase in the initiation of walking time when compared with the corresponding group before ischemia using paired $t$ test $(3.01 \mathrm{sec}$ vs. $0.70 \mathrm{sec}$ ). (I MCAO) group had a significant increase in the initiation of walking time when compared with the corresponding group before ischemia using paired $t$ test $(2.87 \mathrm{sec}$ vs. $0.69 \mathrm{sec})$.

Furthermore, a significant sensorimotor dysfunction was observed in the MCAO groups when compared to sham group as follow:

(A MCAO) group had a significant increase in the initiation of walking time when compared with (A Sham) group (2.93 sec \pm 1.08 vs. $0.65 \mathrm{sec} \pm 0.12$ ). (P MCAO) group had a significant increase in the initiation of walking time when compared with (P Sham) group $(3.01 \mathrm{sec} \pm 1.08$ vs. 
$0.61 \mathrm{sec} \pm 0.14$ ). (I MCAO) group had a significant increase in the initiation of walking time when compared with (I Sham) group (2.87 sec \pm 1.07 vs. $0.66 \mathrm{sec} \pm 0.11$ ).

(Albumin treatment) group had a significant decrease in the initiation of walking time when compared with (A MCAO) group (0.63 sec \pm 0.16 vs. $2.93 \mathrm{sec}$ \pm 1.08 ). (Pioglitazone treatment) group had a significant decrease in the initiation of walking time when compared with (P MCAO) group (0.72 sec \pm 0.22 vs. $3.01 \mathrm{sec}$ \pm 1.08). (Insulin treatment) group had a significant decrease in the initiation of walking time when compared with (I MCAO) group (0.71 sec \pm 0.11 vs. $2.87 \mathrm{sec}$ $\pm 1.07)$.

(Albumin treatment) improved the sensorimotor dysfunction by $78.49 \%$. (Pioglitazone treatment) improved the sensorimotor dysfunction by $76.07 \%$. (Insulin treatment) improved the sensorimotor dysfunction by $75.26 \%$ (fig. 1 , table 1).

\section{Effects on brain edema and leukocyte}

\section{infiltration:}

Photomicrograph (1): (A MCAO) showed neuronal degeneration, microcytic spaces, reactive gliosis and moderate lymphocytic infiltration (bold arrow) (c and d). (P MCAO) showed moderate cerebral edema (bold arrows) (g and h). (I MCAO) group showed mild cerebral edema and leukocyte infiltration (bold arrows) (k and l). (Albumin treatment) group showed granular pink amorphous necrotic white matter (star), ruptured neurons (bold arrow), reactive gliosis, no leukocyte infiltration and no cerebral edema ( $a$ and b). (Pioglitazone treatment) group showed normal white matter (e and f). (Insulin treatment) group showed neuronal damage (star), no leukocyte infiltration and no cerebral edema ( $i$ and $j$ ). Sham groups did not show any brain edema nor leukocyte infiltration ( $\mathrm{m}, \mathrm{n}$, and o).

\section{DISCUSSION}

The current study attempted to investigate the possible protective effects of human serum albumin, pioglitazone and insulin against MCAO which induced brain damage in mice. In the current study, mice subjected to MCAO after $48 \mathrm{~h}$ showed a significant increase the time of initiation of walk test (latency to move test) when compared to sham or before MCAO. Similar changes have been observed by others (Hattori et al., 2000). Who used male C57/B16 mice were subjected to 60 or 90 minutes of intraluminal MCAO or sham surgery. In the first cohort of animals $(n=12$ / group), locomotor activity, balance, and coordination were evaluated 2 weeks after surgery. In a second cohort of animals $(n=10$ / group), the effects of 60 minutes of MCAO on subsequent learning and memory were assessed with a step-down passive avoidance task beginning 1 week after surgery. In a third cohort of animals ( $n=8$ to $10 /$ group), training in a passive avoidance task was completed before 60 minutes of MCAO, then retention of the task was assessed 1 week after surgery. They found that there was a significant increase in latency to move 1 body length in the 90-minute MCAO group compared with the 60-minute MCAO and sham group. Stroke followed by infiltration of leukocytes, release cytokines and chemokines and reactive oxygen species which amplify the brain-inflammatory response, eventually leading to disruption of the BBB, cerebral edema, neuronal death, and hemorrhagic transformation (Kriz, 2006; Amantea et al., 2009). In the present study, mice subjected to MCAO showed significant brain edema while mice subjected to sham operation did not show significant brain edema. These results are in accordance with other researchers (Kahle et al., 2009). Who found that during ischemia, cytotoxic edema occurs in all cells of the neurovascular unit, such as endothelial cell, astrocytes and 
neuronal cells. Cell volume changes, due to minor changes of ion composition in the extracellular or intracellular environment, can significantly affect the function of neurons. Treatment of mice with albumin abolished MCAO induced brain edema. These results are in accordance with other researchers (Belayev et al., 2001). Who reported the beneficial effects of albumin therapy against brain swelling in spraguedawley rats subjected to brain ischemia/ reperfusion. Treatment of mice with pioglitazone also prevented MCAO-induced brain edema. These results are in accordance with other researchers (Medhi et al., 2010; Culman et al., 2012). Treatment of mice with insulin also prevented MCAO-induced brain edema. These results are in accordance with other researchers (Kazan et al., 1999; Panickar et al., 2009). Leukocytes are the cells responsible for the progression from tissue ischemia to cerebral infraction (Lipton, 1999; Frijns and Kappelle, 2002; Huang et $a l ., 2006$ ). The infiltration of leukocytes (in case of cerebral ischemia) and the activation of microglia (the resident immune cells of the brain) (Kochanek and Hallenbeck, 1992) functions to remove damaged tissue, but they have the potential to enhance infract expansion ultimately resulting in more damage in the brain like subsequent micro vessel obstruction, edema formation, cellular necrosis and tissue infarction (Clark et al., 1993). In the current study, mice subjected to MCAO by electrocoagulation for $48 \mathrm{~h}$ showed significant leukocyte infiltration in the ipsilateral hemisphere while sham operation did not show leukocyte infiltration. These results are in accordance with other researchers (Tu et al., 2010). Treatment of mice with albumin prevented leukocyte infiltration following MCAO as previously reported (Piryazev et al., 2014). Similarly, treatment of mice with pioglitazone prevented leukocyte infiltration. This is in accordance with other researchers (Hasegawa et al., 2011; and Culmanet al., 2012). In addition, treatment of mice with insulin had significantly decreased leukocyte infiltration. These results are in accordance with other researchers (Li et al., 2009). MCAO induced cerebral edema, leukocyte infiltration and neuronal death as evidenced by $H \& E$ staining. The infiltration of leukocytes is essential to remove damaged tissue (Kochanek and Hallenbeck, 1992). However, infiltrating leukocytes release cytokines and chemokines and reactive oxygen species which amplify the braininflammatory response, eventually leading to disruption of the $\mathrm{BBB}$, cerebral edema, neuronal death, and hemorrhagic transformation (Kriz, 2006; Amantea et al., 2009).

\section{CONCLUSION}

In conclusion, the current study has clearly demonstrated the neuroprotective effect of intravenous human serum albumin (HSA), oral pioglitazone and intravenous insulin against brain ischemia. 


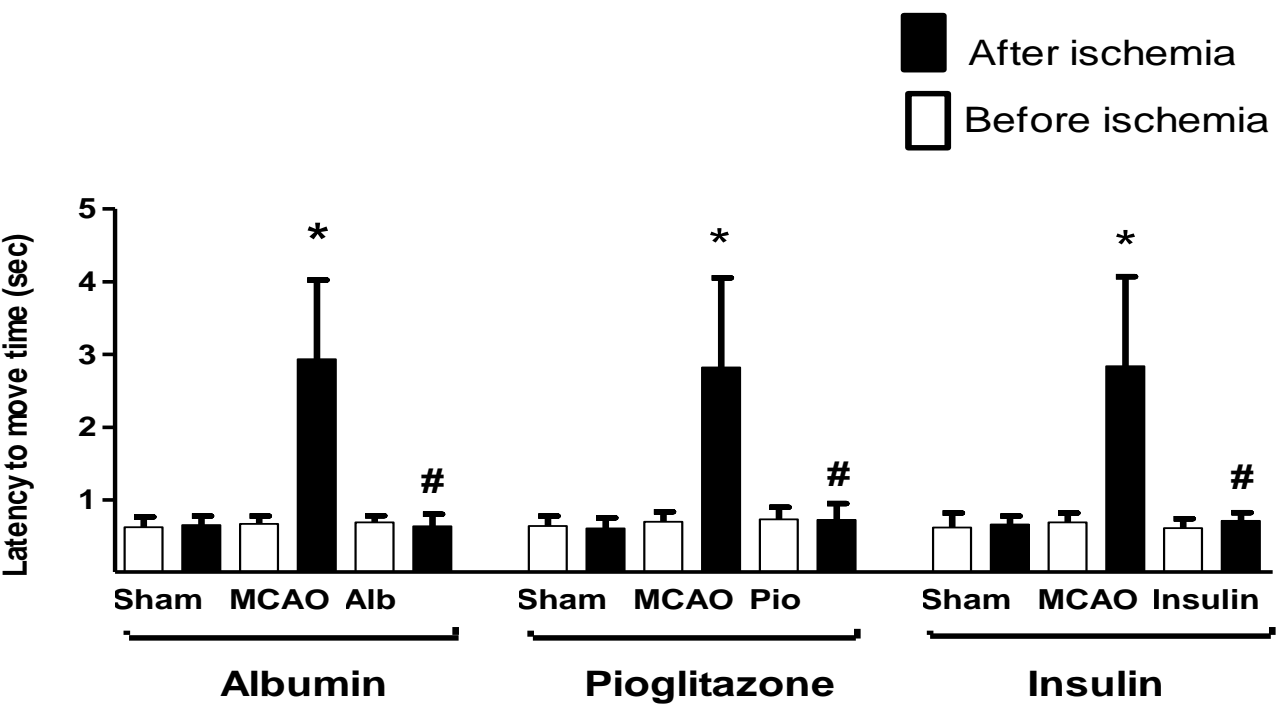

Fig (1): Effect of ischemia and treatment with albumin $(0.04 \mathrm{ml} / 3 \mathrm{~min} / 20 \mathrm{~g}$ \&i.v. infusion), pioglitazone $(40 \mathrm{mg} / \mathrm{kg} /$ day \& oral) and insulin $(0.3 \mathrm{IU} / \mathrm{kg} \& \mathrm{i} . \mathrm{v}$.$) on the sensorimotor function$ measured by initiation-of-walking test

* Significantly difference from the corresponding sham groups.

\#Significantly difference from the corresponding MCAO groups.

Table (1): Effect of ischemia and treatment with albumin $(0.04 \mathrm{ml} / 3 \mathrm{~min} / 20 \mathrm{~g}$ \&i.v. infusion), pioglitazone (40mg/ $\mathrm{kg} /$ day \& oral) and insulin (0.3 IU/ $\mathrm{kg} \&$ i.v.) on the sensorimotor function measured by initiation-of-walking test:

\begin{tabular}{|l|c|c|}
\hline \multicolumn{1}{|c|}{ Group } & $\begin{array}{c}\text { Mean } \pm \text { SD } \\
(\mathbf{s e c})\end{array}$ & $\begin{array}{c}\text { \% Change from the } \\
\text { corresponding MCAO group }\end{array}$ \\
\hline A sham & $0.65 \pm 0.12$ & ---------- \\
\hline A MCAO & $2.93 \pm 1.08^{*}$ & 0 \\
\hline Albumin treatment & $0.63 \pm 0.16 \#$ & $78.49 \%$ \\
\hline P sham & $0.61 \pm 0.14$ & -0 \\
\hline P MCAO & $3.01 \pm 1.08^{*}$ & $76.07 \%$ \\
\hline Pioglitazone treatment & $0.72 \pm 0.22 \#$ & ---------- \\
\hline I sham & $0.66 \pm 0.11$ & 0 \\
\hline I MCAO & $2.87 \pm 1.07^{*}$ & $75.26 \%$ \\
\hline Insulin treatment & $0.71 \pm 0.11 \#$ & \\
\hline
\end{tabular}

*Significantly different from the corresponding sham group at $\mathrm{p}<0.0001$.

\#Significantly different from the corresponding MCAO group at $\mathrm{p}<0.0001$.

Data are expressed as mean $\pm \mathrm{SD}$ 
Zagazig J. Pharm. Sci. June., 2015

Vol. 24, Issue. 1, pp 35-46

Photomicrograph (1): Effect of ischemia and treatment on leukocyte infiltration, cerebral edema and necrotic cell death detected by Hematoxlin and Eosin staining:

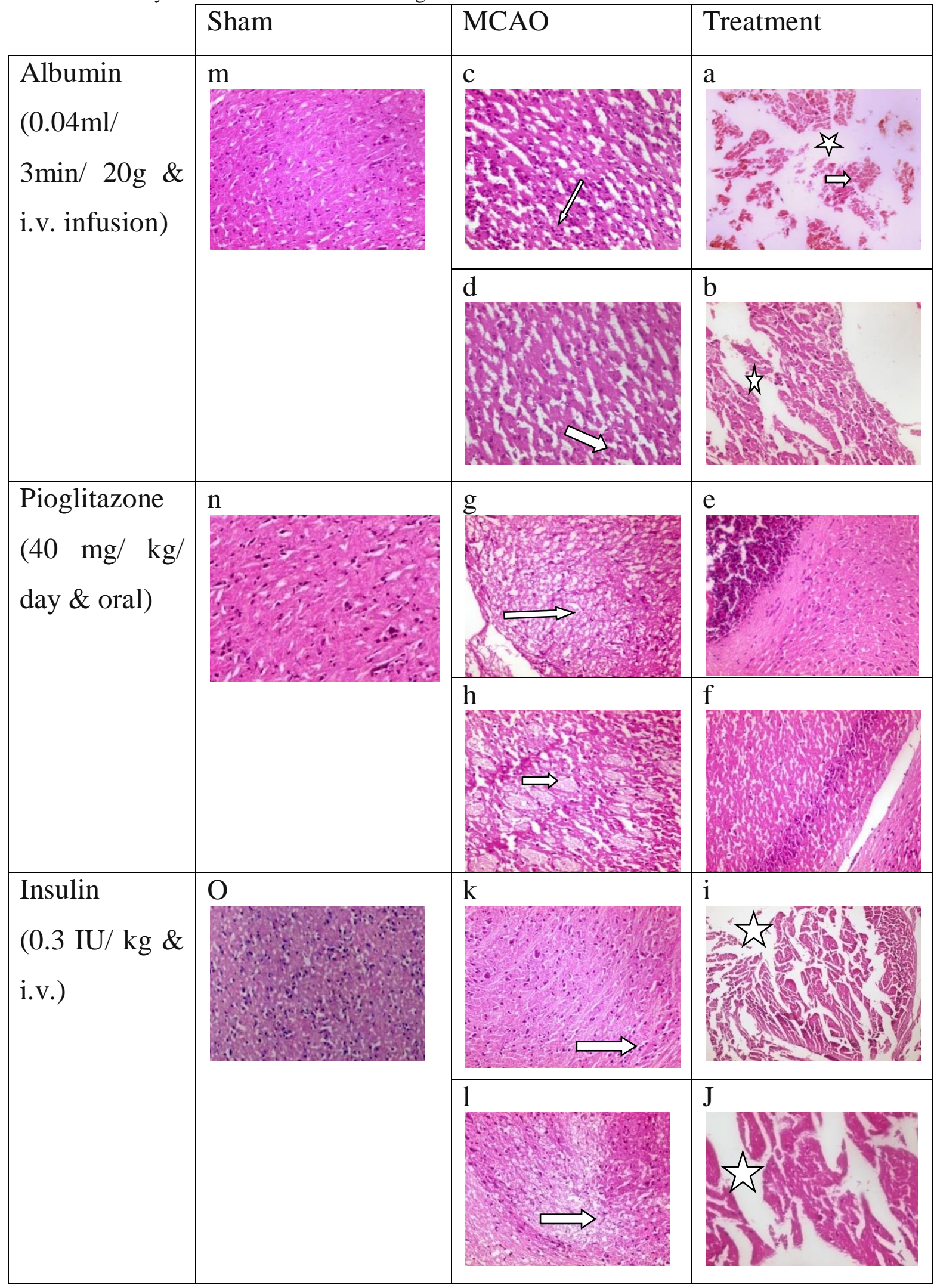




\section{REFERENCES}

Amantea D., Nappi G., Bernardi G., Bagetta G. and Corasaniti M.T. (2009): Postischemic brain damage: pathophysiology and role of inflammatory mediators. Febs J., 276 (1): 13-26.

Aronowski J., Strong R. and Grotta J. C. (1996): Combined neuroprotection and reperfusion therapy for stroke. Effect of lubeluzole and diaspirin cross-linked hemoglobin in experimental focal ischemia. Stroke, 27: 1571-1576.

Avwioro G. (2011): Histochemical Uses OfHaematoxylin- A Review. JPCS., 1: 24-34.

Barakat W., Herrmann O., Baumann B. and Schwaninger M. (2009): NF-kappaB induces PGE2-synthesizing enzymes in neurons. NaunynSchmiedebergs Arch Pharmacol., 380 (2): 153-160.

Barakat W., Safwet N., El-Maraghy N. N. and Zakaria M. N. M. (2014): Candesartan and glycyrrhizin ameliorate ischemic brain damage through down regulation of the TLR signaling cascade. European Journal of Pharmacology, 724: 43-50.

Belayev L., Liu Y., Zhae W., Busto R. and Ginsberg M. D. (2001): Human albumin therapy of acute ischemic stroke: marked neuroprotective efficacy at moderate doses and with a broad therapeutic window. Stroke, 32 (2): 553-560.

Candelario-Jalil E., Thompson J., Taheri S., Grossetete M., Adair J. C., Edmonds E., Prestopnik J., Wills J. and Rosenberg G. A. (2011): Matrix metalloproteinases are associated with increased blood-brain barrier opening in vascular cognitive impairment. Stroke; a journal of cerebral circulation, 42 (5): 1345-1350.

Clark R. K., Lee E. V., Fish C. J., White R. F., Price W. J., Jonak Z. L., Feuerstein G. Z. and Barone F. C. (1993): Development of tissue damage, inflammation and resolution following stroke: an immunohistochemical and quantitative planimetric study. Brain research bulletin, 31 (5): 565-572.

Cohen P. and Goedert M. (2004): GSK3 inhibitors: development and therapeutic potential. Nat Rev Drug Discov., 3 (6):479-487.

Colak G., Filiano A. J. and Johnson G. V. (2011): The application of permanent middle cerebral artery ligation in the mouse. J Vis Exp., 53: e3039.

Cole D. J., Drummond J. C., Patel P. M., Nary J. C. and Applegate R. L. 2nd. (1996). "Effect of oncotic pressure of diaspirin cross-linked hemoglobin (DCLHb) on brain injury after temporary focal cerebral ischemia in rats. AnesthAnalg., 83 (2): 342-347.

Collino M, Aragno M, Castiglia S, Tomasinelli C, Thiemermann C, Boccuzzi G and Fantozzi R. (2009): Insulin Reduces Cerebral Ischemia/ Reperfusion Injury in the Hippocampus of Diabetic Rats: A Role for Glycogen Synthase Kinase-3 beta. Diabetes., 58 (1): 235-242

Culman J., Nguyen-Ngoc M., Glatz T., Gohlke P., Herdegen T. and Zhao Y. (2012): Treatment of rats with pioglitazone in the reperfusion phase of focal cerebral ischemia: a preclinical stroke trial. Exp Neurol., 238 (2): 243-253.

Culman J., Zhao Y., Gohlke P. and Herdegen T. (2007): PPAR-gamma: therapeutic target for ischemic stroke. Trends Pharmacol Sci., 28 (5): 244-249.

Dugo L., Collin M. and Thiemermann C. (2007): Glycogen synthase kinase 3beta as a target for the therapy of shock and inflammation. Shock, 27 (2): 113-123.

Fagan S. C., Hess D. C., Hohnadel E. J., Pollock D. M. and Ergul A. (2004): Targets for vascular protection after acute ischemic stroke. Stroke, 35 (9): 2220-2225.

Frijns C., J. and Kappelle L. J. (2002): Inflammatory cell adhesion molecules in 
ischemic cerebrovascular disease. Stroke, 33 (8): 2115-2122.

Halliwell B. and Gutteridge J. M. (1990): The antioxidants of human extracellular fluids. Arch BiochemBiophys., 280(1): $1-8$.

Hasegawa T., Okada K., Okita Y. and Pinsky D. J. (2011): Antioxidant properties of pioglitazone

limit nicotinamide adenine dinucleotid e phosphate hydrogen oxidase and augment superoxide dismutase activity in cardiac allotransplantation. J Heart Lung Transplant., 30 (10): 1186-1196.

Hattori k., Lee H., Hurn P., Crain B., Traystman R. and DeVries A. (2000): Cognitive deficits after focal cerebral ischemia in mice. Stroke, 31(8): 1939-1944.

Huh P. W., Belayev L., Zhao W., Busto R., Saul I. and Ginsberg M. D. (1998): The effect of high-dose albumin therapy on local cerebral perfusion after transient focal cerebral ischemia in rats. Brain Res., 31; 804 (1): 105-113.

Hui L., Pei D. S., Zhang Q. G., Guan Q. H. and Zhang G. Y. (2005): The neuroprotection of insulin on ischemic brain injury in rat hippocampus through negative regulation of JNK signaling pathway by PI3K/Akt activation. Brain Res., 1052 (1):1-9.

Jiang C., Ting A. T. and Seed B. (1998): PPARgamma agonists inhibit production of monocyte inflammatory cytokines. Nature, 391 (6662): 82-86.

Jørgensen K. A. and Stoffersen E. (1980): On the inhibitory effect of albumin on platelet aggregation. Thromb Res., 17(12): 13-18.

Kahle K. T., Simard J. M., Staley K. J., Nahed B. V., Jones P. S. and Sun D. (2009): Molecular mechanisms of ischemic cerebral edema: role of electroneutral ion transport. Physiology, 24: 257-265.

Kazan S., Karasoy M., Baloğlu H. and Tuncer R. (1999): The effect of mild hypothermia, mannitol and insulininduced hypoglycaemia on ischaemic infarct volume in the early period after permanent middle cerebral artery occlusion in the rat. ActaNeurochir (Wien), 141 (9): 979-987.

Kochanek P. M. and Hallenbeck J. M. (1992): Polymorphonuclear leukocytes and monocytes/ macrophages in the pathogenesis of cerebral ischemia and stroke. Stroke, 23 (9): 1367-1379.

Kriz J. (2006): Inflammation in ischemic brain injury: timing is important. Crit Rev Neurobiol., 18 (1-2): 145-157.

Lakhan S. E., Kirchgessner A. and Hofer M. (2009): Inflammatory mechanisms in ischemic stroke: Therapeutic approaches. J Transl Med., 7: 97.

Lee S. R., Kim H. Y., Hong J. S., Baek W. K. and Park J. W. (2009): PPARgamma agonist pioglitazone reduces matrix metalloproteinase-9 activity and neuronal damage after focal cerebral ischemia. BiochemBiophys Res Commun., 380 (1): 17-21.

Lee Y. B., Yune T. Y., Baik S. Y., Shin Y. H., Du S., Rhim H., Lee E. B., Kim Y. C., Shin M. L., Markelonis G. J. and Oh T. H. (2000): Role of tumor necrosis factoralpha in neuronal and glial apoptosis after spinal cord injury. Exp Neurol., 166 (1): 190-195.

Li J., Wu F., Zhang H., Fu F., Ji L., Dong L., Li Q., Liu W., Zhang Y., Lv A., Wang H., Ren J. and Gao F. (2009): Insulin Inhibits leukocyte-endothelium adherence via an Akt-NO-dependent mechanism inmyocardial ischemia / reperfusion. J Mol Cell Cardiol., 47 (4): 512-515

Lillie R. D. (1965): Histopathologic Technic and Practical Histochemistry, 3rd edition, McGraw-Hill Book Co., New York.

Lipton P. (1999): Ischemic Cell Death in Brain Neurons. Physiol Rev., 79: 1431-1568. 
Lo E. H., Dalkara T. and Moskowitz M. A. (2003): Mechanisms, challenges and opportunities in stroke. Nat Rev Neurosci, 4 (5): 399-415.

Luo Y., Yin W., Signore A. P., Zhang F., Hong Z., Wang S., Graham S. H and Chen J. (2006): Neuroprotection against focal ischemic brain injury by the peroxisome proliferator-activated receptor-g agonist rosiglitazone. J Neurochem., 97 (2): 435-448.

Martinez A., Castro A., Dorronsoro I. and Alonso M. (2002): Glycogen synthase kinase 3 (GSK-3) inhibitors as new promising drugs for diabetes, neurodegeneration, cancer, and inflammation. Med Res Rev., 22 (4): 373-384.

Mayer P. (1896): Mitt. zool. StnNeapel., 12, 303.

Medhi B., Aggarwal R. and Chakrabarti A. (2010):

Neuroprotective effect of pioglitazone o $\mathrm{n}$ acute phase changes induced by partial global cerebral ischemia in mice. Indian J Exp Biol., 48 (8): 793-799.

Marcheselli V. L., Hong S., Lukiw W. J., Tian X. H., Gronert K., Musto A., Hardy M., Gimenez J. M., Chiang N., Serhan C. N. and Bazan N. G. (2003): Novel docosanoids inhibit brain ischemiareperfusion-mediated leukocyte infiltration and pro-inflammatory gene expression. The Journal of biological chemistry, 278: 43807-43817.

Martinez A., Castro A., Dorronsoro I. and Alonso M. (2002): Glycogen synthase kinase 3 (GSK-3) inhibitors as new promising drugs for diabetes, neurodegeneration, cancer, and inflammation. Med Res Rev., 22: 373384.

Muhammad S., Barakat W., Stoyanov S., Murikinati S., Yang H., Tracey K.J., Bendszus M., Rossetti G., Nawroth P. P., Bierhaus A. and Schwaninger M. (2008):
The HMGB1 receptor RAGE mediates ischemic brain damage. J Neurosci., 28: 12023-12031.

Niino M., Iwabuchi K., Kikuchi S., Ato M., Morohashi T., Ogata A., Tashiro K. and Onoé K. (2001): Amelioration of experimental autoimmune encephalomyelitis in C57BL/6 mice by an agonist of peroxisome proliferatoractivated receptor-gamma.

Neuroimmunol., 116 (1): 40-48.

Pereira M. P., Hurtado O., Cárdenas A., AlonsoEscolano D., Boscá L., Vivancos J., Nombela F., Leza J. C., Lorenzo P., Lizasoain I. and Moro M. A. (2005): The nonthiazolidinedionePPARg agonist L796, 449 is neuroprotective in experimental stroke. J NeuropatholExp Neurol., 64 (9): 797-805.

Pfaffl M. W. (2001): A new mathematical model for relative quantification in realtime RT-PCR. Nucleic Acids Res., 29: e45.

Pineau I. and Lacroix S. (2007): Proinflammatory cytokine synthesis in the injured mouse spinal cord: multiphasic expression pattern and identification of the cell types involved. J Comp Neurol., 500 (2): 267-285.

Piryazev A. P., Azizova A. P., Aseichev A. V. andSergienko V. I. (2014): Effect of oxidatively modified and nonmodified human serum albumin on luminal - dependent chemiluminescence of human peripheral blood leukocytes stimulated with opsonized zymosan. Bull ExpBiol Med., 157 (3): 341-343.

Reinhart W. H. and Nagy C. (1995): Albumin affects erythrocyte aggregation and sedimentation. Eur J Clin Invest., 25 (7): 523-528.

Rizk N. N., Rafols J. A. and Dunbar J. C. (2006): Cerebral ischemia-induced apoptosis and necrosis in normal and diabetic rats: effects of insulin and Cpeptide. Brain Res., 1096: 204 -212. 
Rosenberg G. A., Navratil M., Barone F. and Feuerstein G. (1996): Proteolytic cascade enzymes increase in focal cerebral ischemia in rat. Journal of cerebral blood flow and metabolism: official journal of the International Society of Cerebral Blood Flow and Metabolism, 16 (3): 360-366.

Streit W. J., Semple-Rowland S. L., Hurley S. D., Miller R. C., Popovich P. G. and Stokes B. T. (1998): Cytokine mRNA profiles in contused spinal cord and axotomized facial nucleus suggest a beneficial role for inflammation and gliosis. Exp Neurol., 152 (1): 74-87.

Tu X. K., Yang W. Z., Shi S. S., Wang C. H., Zhang G. L., Ni T. R., Chen C. M., Wang R., Jia J. W. and Song Q. M. (2010): Spatio-temporal distribution of inflammatory reaction and expression of TLR2/4 signaling pathway in rat brain following permanent focal cerebral ischemia. Neurochem Res., 35 (8): 1147 1155.

Van Leyen K., Kim H. Y., Lee S. R., Jin G., Arai K. and Lo E. H. (2006): Baicalein and 12/15-Lipoxygenase in the Ischemic Brain. Stroke, 37: 3014-3018.

Wang C. X., Nuttin B., Heremans H., Dom R. and Gybels J. (1996): Production of tumor necrosis factor in spinal cord following traumatic injury in rats. $\mathrm{J}$ Neuroimmunol, 69 (1-2): 151-156.

Wasil M., Halliwell B., Hutchison D. C. and Baum H. (1987): The antioxidant action of human extracellular fluids. Effect of human serum and its protein components on the inactivation of alpha 1antiproteinase by hypochlorous acid and by hydrogen peroxide.Biochem J., 243 (1): 219-223.

Woodruff T. M., Thundyil J., Tang S. C., Sobey C. G., Taylor S. M. and Arumugam T. V. (2011): Pathophysiology, treatment, and animal and cellular models of human ischemic stroke. Mol Neurodegener., 6: 11.

Zhao Y., Patzer A., Gohlke P., Herdegen T. and Culman J. (2005): The intracerebral application of the PPARgamma-ligand pioglitazone confers neuroprotection against focal ischemia in the rat brain. Eur J Neurosci., 22 (1): 278-282.

Zhao X., Ou Z., Grotta J. C., Waxham N. and Aronowski J. (2006a). Peroxisomeproliferator activated receptor-gamma (PPARgamma) activation protects neurons from NMDA excitotoxicity. Brain Res., 1073-1074: 460-469.

Zhao X., Zhang Y., Strong R., Grotta J. C. and Aronowski J. (2006b): 15dProstaglandin J2 activates peroxisome proliferator-activated receptor-gamma, promotes expressionof catalase, and reduces inflammation, behavioral dysfunction, and neuronal loss after intracerebral hemorrhage in rats. J Cereb Blood Flow Metab., 26 (6): 811-820.

Zhao Y., Patzer A., Herdegen T., Gohlke P. and Culman J. (2006c): Activation of cerebral peroxisome proliferatoractivated receptors $\gamma$ promotes neuroprotection by attenuation of neuronal cyclooxygenase-2 overexpression after focal cerebral ischemia in rats. FASEB J. 20 (8): 1162 1175 . 


\section{التاثير العصبي لالبومين المصل البشري, البيوجليتازون والاتسولين علي التلف المخي

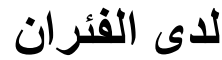

احمد محمد لطفي, وليذ بركات, رشا حسن عبد الغني

السكتة الدماغية هي السبب الرئيسي للوفاة والعجز الدائم لادى البالغين في جميع أنحاء العالم.

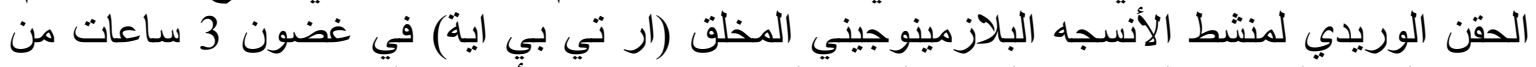

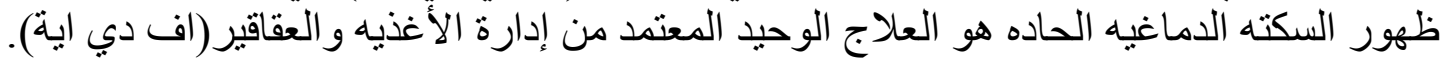

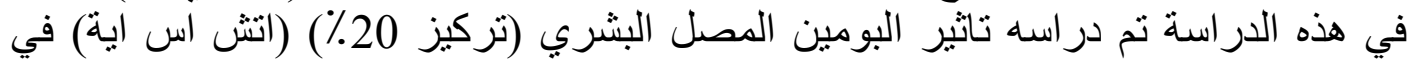

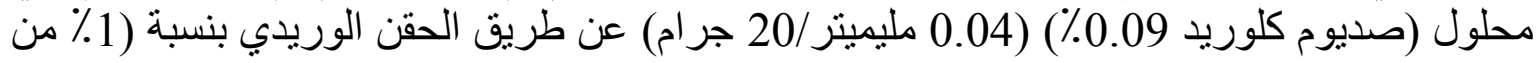

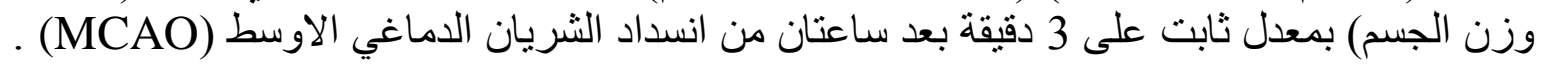

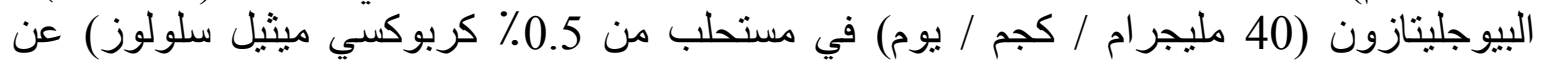

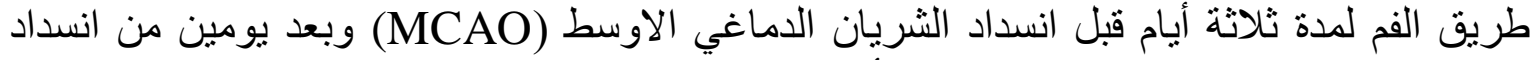

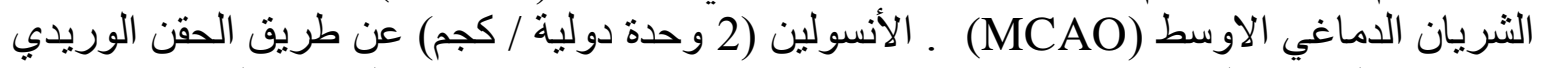
مع انسداد الثريان الدماغي الاوسط (MCAO) وبعد 6 ساعات من انسداد الثريان الدماغي الاوسط

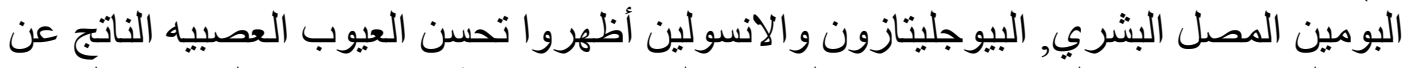
(MCAO)

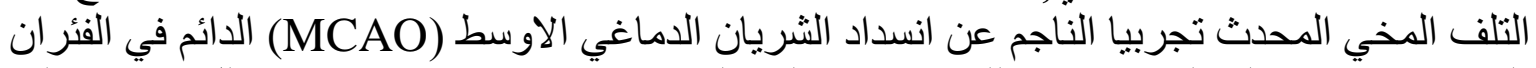

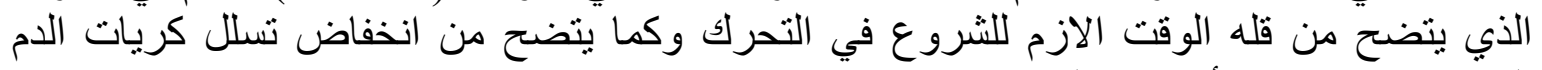
البيضاء وانخفاض الأستقساء الدماغي. 